\title{
ALTERNATIVE REFRIGERANTS FOR HCFC 22-A REVIEW
}

\author{
S.K. Kalla ${ }^{1, *}$, B.B. Arora ${ }^{2}$, J.A. Usmani ${ }^{3}$
}

\section{ABSTRACT}

The aim of this paper is to determine the best available alternative which could replace existing refrigerant R22, with minimum or no changes in the air conditioning system. For this purpose, both the theoretical as well as experimental studies done in this area of research have been reviewed. The most popular HFC, R410A is having lower critical temperature, which restricts its usage in compression based systems working at higher condensing temperatures whereas for $\mathrm{R} 407 \mathrm{C}$, a change to synthetic lubricant is required and HC-290 is flammable. It is suggested that until the safety issue of use of hydrocarbon refrigerants in quantities exceeding $500 \mathrm{gm}$ is resolved, we should go for those mixtures of HFCs and HCs for which TEWI index is the lowest.

\section{Keywords: HCFC, R22, Refrigerant, Alternative, HFC, HC, TEWI}

\section{INTRODUCTION}

R22 has extensively been used in applications like air conditioning, heat pumps, deep freezers and bottle coolers. Since R22 is ozone depleting, it is presently being replaced by HFCs (hydroflorocarbons) like R407C and R410A. As per Kyoto protocol, use of substances having high global warming potential (GWP) like HFCs have to be avoided in the long-term perspective. This underlies the need of searching an alternative refrigerant that is not only having a zero ODP but also possessing a low GWP. Hence extensive research is going on across the globe to find a viable alternative to R22.

Poggi et al. [1] reviewed the efforts to reduce the refrigerant charge in refrigeration systems and concluded that the technical options favorable to charge reduction are (i) the use of refrigerating systems with secondary refrigeration rather than direct refrigeration, (ii) the use of direct expansion fed evaporators rather than flooded evaporators, (iii) the use of hydrocarbon, ammonia or $\mathrm{CO}_{2}$ like refrigerant, and (iv) the use of compact exchangers.

In a similar work, Palm [2] surveyed the use of hydrocarbons insmall air conditioning systems of 0.5 to $3.2 \mathrm{~kW}$ and reported that a minimum room area of $15 \mathrm{~m}^{2}$ is prescribed for a unit with $300 \mathrm{~g}$ charge. During production, extra care is taken for leak detection. The systems are found to have $5-10 \%$ higher efficiency than with HFC.In another review by Calm [3], it was reported that in contrast to R-410A, R-32 avoids the sharp performance decline at higher ambient temperatures and offer both higher seasonal efficiencies and much lower GWPs . It is, however, marginally flammable.

In a review on recent developments in new refrigerant mixtures for vapor compression-based refrigeration, air-conditioning and heat pump units by Mohanraj et al. [4], it was concluded that HC refrigerant mixtures are identified as a long-term alternative to phase out the existing halogenated refrigerants in the vapor compression-based systems.

Environmental effect of using a refrigerant in refrigeration and air conditioning systems is assessed by an indicator known as TEWI (total equivalent warming impact). The method of calculating TEWI is available (AIRAH, 2012). Sarbu [5] based on the TEWI (total equivalent warming impact) index variation grouped possible substitutes for refrigerant R22 into three categories: a) with deviations of $2 \%$ (R417A, R407C, R427A, and R424A); b) with deviations of 30-45\% (R134A, R410A, R290, R600A, and R152A); and c) with deviations of 50-70\% (R507, R404A, R428A, and R422A). For substitutes involved in the b) and c) groups, their use is not recommended because the plant will operate with a significant decrease of refrigeration power. The use of such substitutes is possible only if some changes in the components of the installation are made. 
In order to have an idea of latest scenario in the worldwide efforts for searching an alternative to R22, this paper reviews the studies (theoretical as well as experimental) that have been done so far in order to find an alternative refrigerant that could replace $\mathrm{R} 22$.

\section{ALTERNATIVES AVAILABLE}

\section{Hydrochlorofluorocarbons (HFCs)}

R407C (Ternary mixture of R32/R125/R134a) and R410A (Binary mixture of R32/R125) fall under this category. These are refrigerants containing Hydrogen, Fluorine, and Carbon. Therefore they do not contain any ozone depleting Chlorine. Besides containing no ozone depleting elements, they usually have an even lower global warming potential than HCFCs.

\section{Hydrocarbons (HCs)}

$\mathrm{R} 290\left(\mathrm{C}_{3} \mathrm{H}_{8}\right.$, propane) and propylene (R1270) belong to this category. Several hydrocarbons have excellent thermodynamic properties and can be used as refrigerants. The ODP of hydrocarbons is zero, while their GWP is very small. The main concerns that most of the hydrocarbons are flammable.

\section{Refrigerant Mixtures}

R422A (R125/R134A/R600A), R417A (R125/R134A/R600) andR433A (30\% propylene and $70 \%$ propane) fall under this group. Blends or mixtures are used either to obtain different desired properties such as bubble point temperature, oil solubility, flammability, as drop-in-substitutes for older refrigerants that are no longer produced, etc. by combining different fluids or to obtain variable temperature refrigeration.

\section{Other Natural Refrigerants}

$\mathrm{CO}_{2}$ (R744) and $\mathrm{NH}_{3}$ (R717) belong to this category. Ammonia is an environmentally safe but toxic working fluid which is attracting renewed attention. It possesses the most advantageous thermodynamic and thermophysical properties needed for refrigeration. Carbon dioxide is an excellent refrigerant when both heating and cooling are desired. Also, it is not preferable for use in tropical countries such as India due to the high ambient temperatures which result in high condensing pressures.

\section{COMPARATIVE STUDY OF HFCs, HCs, REFRIGERANT MIXTURES AND NATURAL REFRIGERANTS IN COMPARISON WITH R22}

After a thorough review of the literature on using alternative refrigerants for R22 in window air conditioning system, the findings have been summarised in Table 1.

Table 1. Summary of literature survey

\begin{tabular}{|c|c|c|c|c|c|}
\hline YEAR & AUTHOR & TOPIC & $\begin{array}{c}\text { REFRI- } \\
\text { GERANT } \\
\end{array}$ & PARAMETER & CONCLUSION \\
\hline 1996 & $\begin{array}{l}\text { Lampugnani } \\
\text { and } \\
\text { Zgliczynski }\end{array}$ & $\begin{array}{l}\text { R290 as a Substitute } \\
\text { of R502 and R22 in } \\
\text { Commercial } \\
\text { Refrigeration and } \\
\text { Air Conditioning }\end{array}$ & R290 & $\begin{array}{l}\text { Materials } \\
\text { compatibility, } \\
\text { oil solubility, } \\
\text { operating } \\
\text { temperature }\end{array}$ & $\begin{array}{l}\text { The hermetic compressors, } \\
\text { designed for use with R } 22 \text {, } \\
\text { while operating with } \\
\text { propane show a strong } \\
\text { benefit in terms of general } \\
\text { reliability, due to the lower } \\
\text { bearing loads and the } \\
\text { lower thermal level. It has } \\
\text { a positive influence on the } \\
\text { risk associated to the use } \\
\text { of flammable refrigerants. }\end{array}$ \\
\hline 1997 & Bensafiet al & $\begin{array}{l}\text { Experimental } \\
\text { evaluation of some } \\
\text { proposed } \mathrm{R} 22 \\
\text { alternatives in } \\
\text { chillers and unitary } \\
\text { a/c equipment }\end{array}$ & $\mathrm{R} 407 \mathrm{c}$ & $\begin{array}{l}\text { Capacity and } \\
\text { efficiency }\end{array}$ & $\begin{array}{l}\text { Marginal degradation in } \\
\text { capacity \& EER compared } \\
\text { to R22 }\end{array}$ \\
\hline
\end{tabular}


Table 1. Summary of literature survey

\begin{tabular}{|c|c|c|c|c|c|}
\hline YEAR & AUTHOR & TOPIC & $\begin{array}{c}\text { REFRI- } \\
\text { GERANT }\end{array}$ & PARAMETER & CONCLUSION \\
\hline 1996 & $\begin{array}{l}\text { Lampugnani } \\
\text { and } \\
\text { Zgliczynski }\end{array}$ & $\begin{array}{l}\text { R290 as a Substitute } \\
\text { of R502 and R22 in } \\
\text { Commercial } \\
\text { Refrigeration and } \\
\text { Air Conditioning }\end{array}$ & R290 & $\begin{array}{l}\text { Materials } \\
\text { compatibility, } \\
\text { oil solubility, } \\
\text { operating } \\
\text { temperature }\end{array}$ & $\begin{array}{l}\text { The hermetic compressors, } \\
\text { designed for use with R22, } \\
\text { while operating with } \\
\text { propane show a strong } \\
\text { benefit in terms of general } \\
\text { reliability, due to the lower } \\
\text { bearing loads and the } \\
\text { lower thermal level. It has } \\
\text { a positive influence on the } \\
\text { risk associated to the use } \\
\text { of flammable refrigerants. }\end{array}$ \\
\hline 1997 & Bensafi et al & $\begin{array}{l}\text { Experimental } \\
\text { evaluation of some } \\
\text { proposed R22 } \\
\text { alternatives in } \\
\text { chillers and unitary } \\
\text { a/c equipment }\end{array}$ & R407c & $\begin{array}{l}\text { Capacity and } \\
\text { efficiency }\end{array}$ & $\begin{array}{l}\text { Marginal degradation in } \\
\text { capacity \& EER compared } \\
\text { to R22 }\end{array}$ \\
\hline 2001 & Wang et al & $\begin{array}{l}\text { Rationally based } \\
\text { model for } \\
\text { evaluating the } \\
\text { optimal refrigerant } \\
\text { mass charge in } \\
\text { refrigerating } \\
\text { machines }\end{array}$ & R410A & $\begin{array}{l}\text { COP, } \\
\text { cooling } \\
\text { capacity, } \\
\text { compressor } \\
\text { work }\end{array}$ & $\begin{array}{l}\text { In the early stage of } \\
\text { refrigerant charge process, } \\
\text { a sharp rise of COP is } \\
\text { observed. The COP } \\
\text { reaches an optimal value } \\
\text { for a specified refrigerant } \\
\text { charge and shows a slight } \\
\text { drop for a further increase } \\
\text { of refrigerant charge. }\end{array}$ \\
\hline 2004 & $\begin{array}{c}\text { Roberts and } \\
\text { Chambers }\end{array}$ & $\begin{array}{l}\text { Energy Saving } \\
\text { Refrigerant Blends } \\
\text { Comprising R125, } \\
\text { R134a, R600 or } \\
\text { R600a }\end{array}$ & $\begin{array}{l}\text { R417A \& } \\
\text { Blend } \\
79(\mathrm{R} 125 / \\
\text { R134a/ } \\
\text { R600a } \\
(85.1 \% / 11 . \\
5 \% / 3.4 \%))\end{array}$ & $\begin{array}{l}\text { Energy } \\
\text { efficiency, } \\
\text { GWP }\end{array}$ & $\begin{array}{l}\text { R417A has been } \\
\text { demonstrated as suitable } \\
\text { for the full temperature } \\
\text { range of applications from } \\
\text { air conditioning to low } \\
\text { temperature supermarket } \\
\text { rack systems with no } \\
\text { problems experienced } \\
\text { through lack of capacity } \\
\text { but in every case energy } \\
\text { savings were experienced. } \\
\text { Blend } 79 \text { has been } \\
\text { demonstrated to be } \\
\text { suitable for use as a } \\
\text { replacement for the HCFC } \\
\text { based R502 replacements } \\
\text { without the need for } \\
\text { system or oil changes and } \\
\text { to replace R22 with } \\
\text { minimal changes to the } \\
\text { expansion valves. }\end{array}$ \\
\hline 2005 & Devotta et al & $\begin{array}{l}\text { Performance } \\
\text { assessment of HC- } \\
290 \text { as a drop-in } \\
\text { substitute to HCFC- } \\
22 \text { in a window air } \\
\text { conditioner }\end{array}$ & Propane & $\begin{array}{l}\text { COP, } \\
\text { Discharge } \\
\text { pressure, } \\
\text { cooling } \\
\text { capacity, } \\
\text { energy } \\
\text { consumption }\end{array}$ & $\begin{array}{l}\text { Cooling capacity of HC- } \\
290 \text { was lower in the range } \\
6.6-9.7 \% \text {. Energy } \\
\text { consumption with HC-290 } \\
\text { was lower in the range } \\
12.4-13.5 \% \text {. Discharge } \\
\text { pressures of HC-290 were } \\
\text { lower in the range } 13.7- \\
18.2 \% \text {. }\end{array}$ \\
\hline
\end{tabular}


Table 1. Summary of literature survey

\begin{tabular}{|c|c|c|c|c|c|}
\hline 2005 & Devotta et al & $\begin{array}{l}\text { Performance } \\
\text { assessment of } \\
\text { HCFC-22 window } \\
\text { air conditioner } \\
\text { retrofitted with R- } \\
\text { 407C }\end{array}$ & $\mathrm{R} 407 \mathrm{C}$ & $\begin{array}{l}\text { Cooling } \\
\text { capacity, } \\
\text { coefficient of } \\
\text { performance, } \\
\text { power } \\
\text { consumption, } \\
\text { discharge } \\
\text { pressure }\end{array}$ & $\begin{array}{l}\text { Cooling capacity of R- } \\
407 \mathrm{C} \text { was lower in the } \\
\text { range } 2.1-7.9 \% \text {. Power } \\
\text { consumption with R-407C } \\
\text { was higher in the range } 6- \\
7 \% \text {. Discharge pressures } \\
\text { of R-407C were higher in } \\
\text { the range } 11-13 \% \text {. }\end{array}$ \\
\hline 2008 & Chen and $\mathrm{Yu}$ & $\begin{array}{l}\text { Performance of a } \\
\text { new refrigeration } \\
\text { cycle using } \\
\text { refrigerant mixture } \\
\text { R32/R134a for } \\
\text { residential air- } \\
\text { conditioner } \\
\text { applications }\end{array}$ & $\begin{array}{c}\text { Mixture } \\
\text { R32/R134a }\end{array}$ & $\begin{array}{l}\text { COP, } \\
\text { volumetric } \\
\text { refrigerating } \\
\text { capacity }\end{array}$ & $\begin{array}{l}\text { In the conventional } \\
\text { refrigeration cycle (CRC), } \\
\text { the mixture R32/R134a } \\
\text { has a close performance to } \\
\text { that is obtainable with pure } \\
\text { refrigerant R22. However, } \\
\text { the mixture R32/R134a in } \\
\text { the NRC (new } \\
\text { refrigeration cycle) will } \\
\text { result in a better } \\
\text { performance. The maximal } \\
\text { COP can be improved in a } \\
\text { range of } 8-9 \% \text { over that of } \\
\text { the CRC, and the } \\
\text { volumetric refrigerating } \\
\text { capacity can be } \\
\text { approximately increased } \\
\text { by } 9.5 \% \text {. }\end{array}$ \\
\hline 2009 & Mohanraj & $\begin{array}{l}\text { Environment } \\
\text { friendly alternatives } \\
\text { to halogenated } \\
\text { refrigerants-A } \\
\text { review }\end{array}$ & $\begin{array}{c}\text { R407C and } \\
\text { R410A }\end{array}$ & GWP, ODP & $\begin{array}{l}\text { The choice of alternative } \\
\text { to R22 in air conditioning } \\
\text { applications is R } 407 \mathrm{C} \text { and } \\
\mathrm{R} 410 \text { which are available } \\
\text { in the Indian market }\end{array}$ \\
\hline 2011 & Bolaji & $\begin{array}{l}\text { Performance } \\
\text { investigation of } \\
\text { ozone-friendly } \\
\text { R404A and R507 } \\
\text { refrigerants as } \\
\text { alternatives to R22 } \\
\text { in a window air- } \\
\text { conditioner }\end{array}$ & $\begin{array}{c}\text { R404A and } \\
\text { R507 }\end{array}$ & $\begin{array}{l}\text { Pressure ratio, } \\
\text { discharge } \\
\text { temperature, } \\
\text { compressor } \\
\text { power and } \\
\text { energy } \\
\text { consumption, } \\
\text { refrigeration } \\
\text { capacity, } \\
\text { coefficient of } \\
\text { performance }\end{array}$ & $\begin{array}{l}\text { The average discharge } \\
\text { temp obtained using R507 } \\
\text { and R404A were } 4.2 \% \text { and } \\
15.3 \% \text { higher than that of } \\
\text { R22, respectively } \\
\text { The lowest compressor } \\
\text { power and energy } \\
\text { consumption were } \\
\text { obtained from R507 } \\
\text { retrofitted system. The } \\
\text { average refrigeration } \\
\text { capacities of R507 and } \\
\text { R404A were } 4.7 \% \text { higher } \\
\text { and } 8.4 \% \text { lower than that } \\
\text { of R22, respectively. } \\
\text { Average COP of R507 } \\
\text { increased by } 10.6 \% \text { and } \\
\text { that of R404A reduced by } \\
16.0 \% \text { with respect to that } \\
\text { of R22. }\end{array}$ \\
\hline
\end{tabular}


Table 1. Summary of literature survey

\begin{tabular}{|c|c|c|c|c|c|}
\hline 2011 & $\begin{array}{c}\text { Chinnaraj et } \\
\text { al }\end{array}$ & $\begin{array}{l}\text { Influence of } \\
\text { Electronic } \\
\text { Expansion } \\
\text { Valve on the } \\
\text { Performance of } \\
\text { Small Window } \\
\text { Air Conditioner } \\
\text { Retrofitted With } \\
\text { R407c and R290 }\end{array}$ & $\begin{array}{l}\text { R407C and } \\
\text { R290 }\end{array}$ & $\begin{array}{l}\text { Degree of } \\
\text { superheat, COP }\end{array}$ & $\begin{array}{l}\text { The electronic expansion } \\
\text { valve shows good overall } \\
\text { performances comparing } \\
\text { the capillary tube system. } \\
\text { The coefficient of } \\
\text { performance of R } 290 \text { is } \\
\text { the maximum among the } \\
\text { three refrigerants tested }\end{array}$ \\
\hline 2012 & Wu et al & $\begin{array}{l}\text { Study of R161 } \\
\text { Refrigerant for } \\
\text { Residential Air } \\
\text { conditioning } \\
\text { Applications }\end{array}$ & R161 & $\begin{array}{l}\text { Cooling } \\
\text { capacity, COP, } \\
\text { Discharge } \\
\text { temperature }\end{array}$ & $\begin{array}{l}\text { Cooling capacity reduced } \\
7.6 \% \text { 2. cooling EER } \\
\text { increased } 6.1 \% \\
\text { Refrigerant optimized } \\
\text { charge reduced } 43 \% \\
\text { compared to } 22 . \\
\text { R161 has lower discharge } \\
\text { temperature }\end{array}$ \\
\hline 2013 & $\begin{array}{l}\text { Padmanab- } \\
\text { han \& } \\
\text { Palanisamy }\end{array}$ & $\begin{array}{l}\text { Exergy efficiency } \\
\text { and irreversibility } \\
\text { comparison of R22, } \\
\text { R134a, R290 and } \\
\text { R407C to replace } \\
\text { R22 in an air } \\
\text { conditioning system }\end{array}$ & $\begin{array}{l}\text { R134a, } \\
\text { R290 and } \\
\text { R407C }\end{array}$ & $\begin{array}{l}\text { Exergy } \\
\text { efficiency, } \\
\text { irreversibility }\end{array}$ & $\begin{array}{l}\text { The refrigerant } \mathrm{R} 290 \text { is the } \\
\text { best performer among } \\
\text { candidate refrigerants but } \\
\text { it suffers from } \\
\text { flammability. Thus, } \\
\text { R407C can considerably } \\
\text { be used to replace R } 22 \text {. }\end{array}$ \\
\hline 2014 & Ramu et al. & $\begin{array}{l}\text { Energy } \\
\text { Performance } \\
\text { Assessment of } \\
\text { R32/R125/R600a } \\
\text { Mixtures as } \\
\text { Possible } \\
\text { Alternatives to R22 } \\
\text { in Compression } \\
\text { Refrigeration } \\
\text { Systems }\end{array}$ & $\begin{array}{l}\text { R32/R125/ } \\
\text { R600a } \\
\text { (in the ratio } \\
\text { of } \\
0.4: 0.4: 0.2 \text {, } \\
\text { by mass) }\end{array}$ & $\begin{array}{l}\text { Coefficient of } \\
\text { performance } \\
\text { (COP), } \\
\text { compressor } \\
\text { power } \\
\text { consumption, } \\
\text { compressor } \\
\text { discharge } \\
\text { temperature } \\
\text { and volumetric } \\
\text { cooling } \\
\text { capacity } \\
\text { (VCC). Total } \\
\text { equivalent } \\
\text { global warming } \\
\text { impact } \\
\text { (TEGWI) }\end{array}$ & $\begin{array}{l}\text { 1. VCC of new refrigerant } \\
\text { mixture is closer to R } 22 \\
2 . \text { COP of the mixture was } \\
\text { found to be lower by about } \\
16-20 \% \\
\text { 3. Compressor discharge } \\
\text { temp of the new } \\
\text { refrigerant mixture was } \\
\text { observed to be } 6-11^{\circ} \mathrm{C} \\
\text { lower } 3 \text {. TEGWI of new } \\
\text { refrigerant mixture was } \\
\text { found to be higher than } \\
\text { that of R22 by about } 20 \%\end{array}$ \\
\hline 2014 & Samuel et al & $\begin{array}{l}\text { An Experimental } \\
\text { Investigation and } \\
\text { Performance } \\
\text { Evaluation of } 1.5 \\
\text { TR Window } \\
\text { Air-Conditioner by } \\
\text { Using R22, R407C } \\
\text { and R410A by } \\
\text { Varying the } \\
\text { Capillary Pitch }\end{array}$ & $\begin{array}{c}\text { R407C } \\
\text { and } \\
\text { R410A }\end{array}$ & $\begin{array}{l}\text { COP, } \\
\text { compressor } \\
\text { power, heat } \\
\text { rejection ratio }\end{array}$ & $\begin{array}{l}\text { R410A with a capillary } \\
\text { pitch of } 18 \mathrm{~mm} \text { gave the } \\
\text { best Coefficient of } \\
\text { performance to retrofit an } \\
\text { window air conditioner } \\
\text { working on R22. }\end{array}$ \\
\hline
\end{tabular}




\section{Hydro-Fluorocarbons (HFCs)}

\section{Based on Evaporator Temperature}

Below $-30^{\circ}$ Carora et al. [6] performed a theoretical analysis of a vapour compression refrigeration system with R-407C and R-410A using Engineering Equation Solver software for evaporator temperatures between $-38^{\circ} \mathrm{C}$ to $7^{\circ} \mathrm{C}$ and concluded that $\mathrm{COP}$ and exergetic efficiency for R-22 were higher in comparison to R-407C and R-410A. DuPont [7] in their technical information paper tested the performance of R422A at an evaporator temperature of $-35^{\circ} \mathrm{C}$ in a low temperature direct expansion refrigeration system and found discharge temperature to be lower by $8 \mathrm{~K}$ and COP higher by $16 \%$ as compared to R22. Menlik et al. [8] theoretically analysed the performance (in terms of energy and exergy aspects) of a vapour compression refrigeration system working with R22 and its alternatives R407C and R410A. It was reported that R407C has higher COP, less EDR and higher exergetic efficiency than R410A. With increase in subcooling/superheating temperature, COP of R22, $\mathrm{R} 407 \mathrm{C}$ and R410A increase. R407C has $10 \%$ higher exergetic efficiency than R410A between $20^{\circ} \mathrm{C}$ and $35^{\circ} \mathrm{C}$ dead state temperature.

Between $-30^{\circ} \mathrm{C}$ to $0^{\circ} \mathrm{C}$, Klein et al. [9] theoretically studied a vapour compression refrigeration system operating at an evaporating temperature of $-20^{\circ} \mathrm{C}$ and reported that liquid-suction heat exchangers that have a minimal pressure loss on the low pressure side are useful for systems using R507A, R134A, R12, R404A, R290, R407C, R600, and R410A. Grace and Tassou [10] simulated the performance of R407C, R134A, R404A and R507A in a liquid chiller and their results showed that for typical air-conditioning applications, R407C is the preferred alternative to R22, with R134A being an option at lower evaporating temperatures, although this would require a replacement compressor in order to produce comparable cooling capacities. R407C has a high glide temperature which can lead to composition changes after leakage and may require some valve adjustment.

In a theoretical analysis conducted with R134a, R404A, R407C, R410A, and R507 and three natural refrigerants at evaporating temperatures ranging from $-30^{\circ} \mathrm{C}$ to $10^{\circ} \mathrm{C}$, it was reported that for air conditioning and heat pumps, R407C, R410A, R134A exhibit excellent performance, and could be proposed to replace R22 in these applications (Boumaza [11]). In related work, Rani and Balachander [12] simulated the performance of an R22 system working with R407C by using MATLAB software. It has been reported that performance degradation shall be minimized by selecting a slightly higher condensation temp for R407C (than R22), without changing mass flow rate. Jia [13] in a study done at an evaporating temperature of $-4^{\circ} \mathrm{C}$ suggested that R404A and $\mathrm{R} 410 \mathrm{~A}$ represent a good balance of system performance, product safety and environmental impact. In an experimental assessment with $\mathrm{R} 422 \mathrm{D}$ as an alternative to R22 in walk-in air cooler, it has been reported that COP of R422D was lower than that of R22 (Aprea et al. [14]). In an experimental study, Han et al. [15] concluded that in a small scale refrigeration system using HFC-161, it was possible to achieve higher COP by 15-25\% than HFC-410A and HFC-32. In another work, Padmanabhan \&Palanisamy [16] tested the refrigerants R134A, R290 and R407C in the VCRS of an air conditioner and reported that the refrigerant R290 was the best performer among candidate refrigerants but it suffered from flammability. Thus, R407C could considerably be used to replace R22. Similarly, Bolaji et al. [17] (2014) theoretically assessed the performance of R432A and $\mathrm{R} 433 \mathrm{~A}$ in a VCRS at an evaporating temperature of -30 to $10^{\circ} \mathrm{C}$ and reported that the average COPs obtained for R432A and R433A were lower by only 4.5 and 5.4\%, respectively, than those of R22. La Rocca et al. [18] investigated R413A, R417A, R422A and R422D in a low-temperature refrigerating unit to replace R22 and reported that COP was lower for all the replacement fluids showing inferior energy efficiency and higher energy consumption.

Between $0^{\circ} \mathrm{C}$ to $15^{\circ} \mathrm{C}$, Hewitt \& McMullan [19] studied the performance of HFC R407C in a R22 compressor and reported deterioration in performance with decreasing evaporator temperature compared to that of R22. Johansson \&Lundqvist [20] performed simulation as well as field tests in chillers at an evaporating temperature of $6^{\circ} \mathrm{C}$ working with R134A, Propane, R404A, R407C and lsceon 59 refrigerants. It was reported that to make the system perform its best with lsceon 59 the area used for subcooling had to be larger than when R22 were used. With other substitutes, like R134A, a smaller subcooling area gave the maximum performance of the system. Devotta et al. [21] in their simulation study assessed the performance of a VCRS at an evaporating temperature of $7.2^{\circ} \mathrm{C}$ using CYCLE_D software working with HFC-134A, HC-290, R-407C, R-410A, and three blends of HFC-32, HFC-134A and HFC-125. Their results reported that R-407C is mainly used for retrofitting whereas R-410A is the next popular choice for new systems. Johansson \&Lundqvist [22] reported that R407C is 
suitable for retrofitting whereas R410A could be used for new air conditioners. Calm \&Domanski [23] suggested that R410A is the leading replacement for redesigned window air conditioners. Horuz [24] studied the alternatives for R22 and concluded that possible alternatives for R22 are R407C, R410A and R410B. Chen and $\mathrm{Yu}$ [25] theoretically analysed the performance of a residential air-conditioner (at evaporating temperature of $5^{\circ} \mathrm{C}$ ) working with mixture R32/R134a. It was reported that the mixture R32/R134A in the NRC (new refrigeration cycle) will result in an improved COP in a range of $8-9 \%$ over that of the CRC (conventional refrigeration cycle), and the volumetric refrigerating capacity can be approximately increased by $9.5 \%$. Allgood [26] suggested in an ASHRAE report that R422D suited to supermarket application whereas R410A/R407C suited to air conditioning. Emerson Network Power [27] in their technical note reported that R410A and R407C offer equivalent performance and higher capacity alternatives to R22. Currently R410A is being used extensively for most new, small residential air-cooled systems. Honeywell [28] in their study suggested that for unitary air conditioning, R407C and R410A are environmentally safer alternatives. Department for Environment, Food and Rural Affairs, UK [29] reported that for larger industrial refrigeration and air-conditioning systems ammonia is a well-established refrigerant which can provide a high efficiency system. For very small systems hydrocarbons such as iso-butane have become well established whereas $\mathrm{CO}_{2}$ has been used successfully in small systems, in larger commercial refrigeration systems and in some industrial applications. BITZER [30] reported that R407C is short term substitution for R22 as performance \& efficiency are very similar. R410A has $50 \%$ higher volumetric cooling capacity but a proportional rise in system pressure whereas R438A was designed for higher critical temperature for hot climate areas. Bolaji [31] has experimentally evaluated the performance of a splitair-conditioner (at evaporator temperatures between $2{ }^{\circ} \mathrm{C}$ to $12^{\circ} \mathrm{C}$ ) working with $\mathrm{R} 410 \mathrm{~A}$ and $\mathrm{R} 417 \mathrm{~A}$ as an alternative to R22. His results reported that the average COP with R417A and R410A were found to be $2.9 \%$ higher and $8.4 \%$ lower, respectively, than that with R22.

\section{Based on Cooling Capacity}

Up to $3.5 \mathrm{~kW}$ capacity, Vjacheslav et al. [32] theoretically assessed the performance of a $3 \mathrm{~kW}$ air conditioner working with R410A and reported that in the early stage of refrigerant charge process, a sharp rise of $\mathrm{COP}$ is observed. The COP reaches an optimal value for a specified refrigerant charge and shows a slight drop for a further increase of refrigerant charge. Aprea and Renno [33] experimentally assessed the performance of a $1.6 \mathrm{~kW}$ experimental vapour compression refrigeration plant, applied to a commercially available cold store working with R417A. It was reported that the percentage difference between the COP of the fluids experimentally tested is, on average, about $15 \%$. Moreover, the exergy destroyed in the plant components when R417A is used as working fluid is, on average, about $14 \%$ higher than the exergy destroyed with R22. Spatz \& Motta [34] theoretically analysed the performance of a $0.5 \mathrm{~kW}$ walk-in cooler working with 404A, R-410A and R-290 and concluded that environmentally acceptable alternative is R-410A. Chen [35] performed a simulation study of split-type residential air conditioner of $3.55 \mathrm{~kW}$ capacity using Genesym software working with R410A. It was reported that adoption of R410A could be helpful for air conditioner to decrease their heat exchanger size or improve their operation efficiency for power saving. Similarly, Mohanraj et.al. [36] reviewed the performance of environment friendly refrigerants for room air conditioners and concluded that the choice of alternative to R22 in air conditioning applications is R407C and R410 which are available in the Indian market. Wang et al. [37] experimentally studied the performance of a process cooling system at $-15^{\circ} \mathrm{C}$ working with HFC-404A. Their results indicated that retrofitted system using HFC-404A refrigerant can achieve similar cooling performance as the HCFC-22 system in addition to the temperature control accuracy for process cooler requirement. In an experimental study on residential air conditioner of $3.5 \mathrm{~kW}$ capacity using R161, it was concluded that the cooling capacity reduced $7.6 \%$, cooling EER increased $6.1 \%$, refrigerant optimized charge reduced $43 \%$ compared to R22 and R161 had lower discharge temperature (Wu et al. [38]). Aprea et al. [39] tested the performance of a walk-in cooler working with R422D and their results reported that COP of R422D is $20 \%$ lower than that of R22. Furthermore, for plant whose condenser is air cooled, R422D could lead to increase the fan speed or to adopt bigger blowers.

$3.5 \mathrm{~kW}$ to $7 \mathrm{~kW}$ capacity, Bensafi et al. [40] tested the performance of a room air conditioner of $6 \mathrm{~kW}$ capacity working with HFC R407C and reported marginal degradation in capacity \& EER compared to R22. Aprea \& Greco [41] have experimentally investigated the performance with HFC 407C in a $5 \mathrm{~kW}$ vapour compression plant to replace R22. Their results reported that in order to increase the overall performance of the vapour compression plant working with $\mathrm{R} 407 \mathrm{C}$, the evaporator and the compressor must be optimized. In a 
similar work, the performance of a window air conditioner of $5.13 \mathrm{~kW}$ capacity working with $\mathrm{R} 407 \mathrm{C}$ was experimentally assessed and it was reported that the cooling capacity of R-407C was lower in the range $2.1-$ $7.9 \%$, power consumption with R-407C was higher in the range 6-7\% and discharge pressures of R-407C were higher in the range 11-13\% (Devotta et al. [42]). Bolaji [43] experimentally assessed the performance of a window air-conditioner of $3.86 \mathrm{~kW}$ capacity working with R404A and R507. It was concluded that R507 can be used successfully as a retrofitting refrigerant in existing window air-conditioners originally designed to use R22. Samuel et al. [44] experimentally assessed the performance of a $5.27 \mathrm{~kW}$ window air-conditioner working with R407C and R410A. Their results indicated that R410A with a capillary pitch of $18 \mathrm{~mm}$ gave the best Coefficient of performance to retrofit a window air conditioner working on R22.

Above $7 \mathrm{~kW}$ capacity, Payne \& Domanski [45] have experimentally evaluated the performance of a 9.5 $\mathrm{kW}$ split air-conditioning system working with $\mathrm{R} 410 \mathrm{~A}$ as an alternative. Their results reported that while capacities of both systems were approximately equal at the $35.0^{\circ} \mathrm{C}$ rating point, at the $54.4^{\circ} \mathrm{C}$ outdoor temperature the R410A capacity was $9 \%$ below that of R22. For the same test points, the R410A COP was $4 \%$ and $15 \%$ lower than the R22 COP, respectively. In another experimental study on $11 \mathrm{~kW}$ walk-in refrigeration system working with R-290, R-404A and R-410A, it was reported that R-410A has less or equivalent environmental impact as compared to R-290 when safety (toxicity and flammability), environmental impact (climate change), cost and performance (capacity and COP) are considered (Hwang [46]). Kulcar et al. [47](2010) theoretically analysed the performance of a $215 \mathrm{~kW}$ cooling system for preparing chilled water working with R407C. Their results concluded that by using refrigerant R407C, the consumption of electrical energy needed for the running of compressors is reduced, thus helping to keep our environment cleaner. In a similar study, Rocca \&Panno [48] tested R22, R417A, R422A and R422D in a $25 \mathrm{~kW}$ vapour compression refrigerating unit and their results showed that despite the case of substitution and the advantage of being able to continue to use mineral oil as a lubricant in the compressor, the performance with the new tested fluids did not result as efficient as when using R22. Rocca et al. [49] compared the performance of a $25 \mathrm{~kW}$ refrigerating plant working with R417A, R407CandR404A. They reported that substituting a pure HCFC fluid such as R22 is disadvantageous since the different replacement fluids give a less satisfactory rendering due to their particular thermophysical properties in a system sized for the given original fluid. TEWI increment may be far more damaging than the low ODP of the original fluid. Jain et al. [50] theoretically assessed the performance of a $66.67 \mathrm{~kW}$ VCRS using R134A/R410A/R407C/M20 and their results indicated that R407C can be a potential HFC refrigerant replacement for new and existing systems presently using R22 with minimum investment and efforts. Qureshi and Zubair [51] theoretically assessed the performance of a $100 \mathrm{~kW}$ VCRS working with R134A, R410A, R407C/ R717, R404A, R290 by using EES software. Their results indicated that considering R134A, R410A and R407C from a first law standpoint, the COP indicates that R134a always performs better unless only the evaporator is being fouled. Volumetric efficiency of R410A remained the highest.

\section{Based on Changes in Components of the System}

Lee et al. [52] experimentally evaluated the performance of a $100 \mathrm{~kW}$ commercial screw chiller with shell-and-tube heat exchangers working with R407C. They reported that the cooling capacity decreases by $10-$ $20 \%$ and the COP by $20-30 \%$ depending on the temperature condition as compared to R22. Aprea et al. [53] experimented with R417A, R507 and R407C in a vapour compression refrigeration plant subjected to a commercially available cold store. During their experimentation, the operating temperatures were maintained at 32 and $10^{\circ} \mathrm{C}$ (condenser temperature) and $5,0,-5,-10$ and $-15^{\circ} \mathrm{C}$ (evaporator temperature). It has been reported that by using the $\mathrm{R} 407 \mathrm{C}$, it is possible an average electric energy consumption about $12 \%$ smaller when an inverter is employed to control the compressor refrigeration capacity instead of the thermostatic control which imposes on/off cycles on the compressor, working at the nominal frequency of $50 \mathrm{~Hz}$. Llopis [54] experimentally assessed the performance of a double-stage vapour compression plant driven by a compound compressor working with HFC-422A and the HFC-417B. It was reported that there is a reduction in cooling capacity and in $\mathrm{COP}$ with regard to the HCFC-22 operation. In a related work, a $1 \mathrm{~kW}$ VCRS with two-stage and intercooler was theoretically investigated by using Solkane software working with R507, R407C and R404A. The results indicated that COP and exergy efficiency of the system using R407C is better than the other refrigerants. Subiantoro and Ooi [55] theoretically analysed the performance of a $5.27 \mathrm{~kW}$ medium scale air conditioning system working with CO2, R134A, NH3, R32, R404A, R1234yf, R410A, R407C and R438A. It was reported that the use of expanders in commercial refrigeration systems not only reduces the environmental impact of the 
systems, but also has practical payback periods for both the conventional and especially, the transcritical $\mathrm{CO} 2$ systems.

\section{Performance Comparison}

The coefficient of performance comparison (COP) of R407C and R410A with respect to R22 has been shown in Figure 1 (Menlik et. al. [8]) whereas the variation of exergetic efficiency with condenser temperature is shown in Figure 2 (Menlik et al. [8]).

\section{Hydrocarbons (HCs)}

\section{Based on evaporator temperature}

Below $-30^{\circ} \mathrm{C}$ Jürgensen [56] in his study for commercial refrigerated appliances suggested that the energy efficiency and reliability of the appliance using R290 is expected to be equivalent to or better than that of equipment using R22. Because R290 has no ODP and a very low GWP, assuming that R290 has the same energy efficiency as R22, the environmental impact is reduced. Saleh and Wendland [57] simulated the performance of a vapour compression refrigeration system at an evaporating temperature of $-40^{\circ} \mathrm{C}$ and a condensing temperature of $30^{\circ} \mathrm{C}$ working with propane and propylene. Their results showed that propane and propylene are alternative for R22.

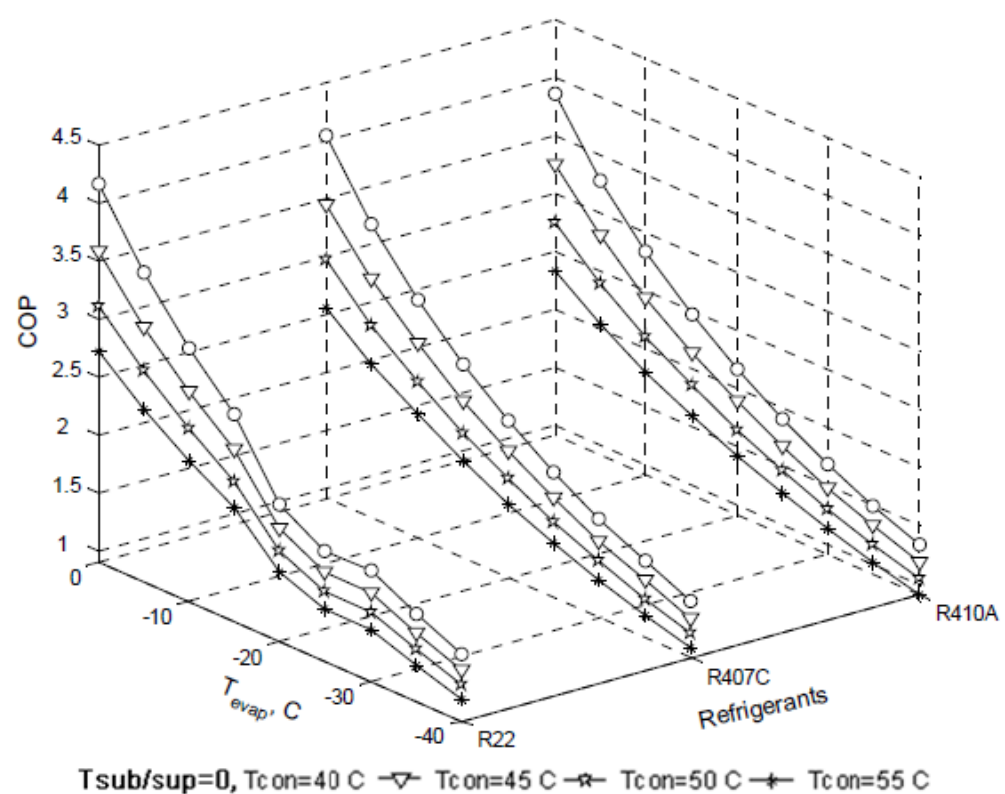

Figure 1. Comparison of COP of R22, R407C and R410A with evaporator temperature at different condenser temperatures [8]

Between $-30^{\circ} \mathrm{C}$ to $10^{\circ}$ CGranryd [58] comprehensively reviewed the performance of hydrocarbons as refrigerants in various applications and suggested that commercial "hydrocarbon chillers" are available on the market for low temperature applications $\left(-35^{\circ} \mathrm{C}\right)$ as well as for comfort cooling $\left(+6^{\circ} \mathrm{C}\right)$ and for heat pumps. Copetti et al. [59] theoretically analysed the performance of Propane and Isobutane in a $1 \mathrm{~kW}$ refrigeration system at an evaporation temperature between $-20^{\circ} \mathrm{C}$ to $10^{\circ} \mathrm{C}$ and condenser temperature of $40^{\circ} \mathrm{C}$. Their results concluded that the hydrocarbon presenting better performance for R22 substitution, in the range of temperatures analyzed, was R600a. The propane presents for the same range of temperature a slightly inferior performance. In a related work, Park \& Jung [60] tested the performance of R290 and R1270 in a $3.5 \mathrm{~kW}$ heat pump bench tester and their results concluded that COPs of R290 and R1270 are up to 12\% higher than those of R22. These hydrocarbons provide good performance with reasonable energy savings without any environmental problems. In a similar work, Bayrakci and Ozgur [61] studied the performance of a 1kW VCRS at an evaporating temp of 25 to $0^{\circ} \mathrm{C}$ and a condensing temperature of 30 to $50^{\circ} \mathrm{C}$ working with R1270, R600, R600a and R290. Their results showed that in the point of view of energy and exergy efficiency, the best alternative refrigerant is R1270 
for R22 and R134a. Differences of coefficient of cooling performance values of these refrigerants are quite small. Park et al. [62] experimentally investigated the performance of R170/R1270 mixture (R170 varied from 0 to $10 \%$ with an interval of $2 \%$ ) as alternatives to R22 in a $3.5 \mathrm{~kW}$ heat pump bench tester. They reported that pure propylene and R170/R1270 mixture are good long-term candidates to replace R22 in residential air conditioners and heat pumps from the viewpoint of energy efficiency and greenhouse warming. Dalkilic \& Wongwises [63] theoretically predicted the performance of a VCRS at a condensation temperature of $50{ }^{\circ} \mathrm{C}$ using different refrigerant blends R-290/R-1270 (20/80), R-290/R-1270 (50/50), R-290/R-1270 (60/40), R290/R-1270 (80/20), R-290/R-152A (60/40), R-32/R-134A (30/70) (the refrigerant mixture blending being on mass basis). It has been reported that the refrigerant blend of $\mathrm{HC} 290 / \mathrm{HC} 1270$ (20/80 by wt. \%) is found to be the most suitable alternative among refrigerants tested for R22. Boumaza [64] simulated the performance of VCRS using refrigerant R290, R600A and R717 as alternatives to R22. It was revealed that the examined new refrigerants show varying performance, depending on the evaporator temperatures, but in every case, the condenser temperature seems to have an important impact on the performance of the cycle. Wan et al [65] reported that residential air-conditioner with HC-290 will produce more environmental benefits compared with HFC-410A, due to a high reduction of greenhouse gas emissions which slows down global warming. Farraj et al. [66] experimentally compared the performance of R22 and Liquefied Petroleum Gas Mixture (LPGM) of $30 \%$ propane, R-290 and $70 \%$ butane, R-600, (weight ratio) in a one ton split air conditioning unit (A/C) powered by solar energy. Their results showed that although systems using LPGM had lower COP and lower capacity than those using R-22, the first systems had the advantages of higher refrigeration effect, lower mass flow rate, lower energy consumption and lower compressor exit temperature. Prapainop and Suen [67] investigated the performance of some common refrigerants, including R22, following two approaches of refrigerant comparison for retrofit replacement. Using both the methods of full simulation as well as refrigerant thermo-physical properties and cycle performance analysis, it was concluded that in general the full simulation results agree well with the experimental results. Bolaji and Huan [68] analysed the performance characteristics of a vapour compression refrigeration system at $-20^{\circ} \mathrm{C}$ evaporating temperature working with three hydrocarbons R290, R600A and R1270. Their results indicated that the degree of sub-cooling greatly increased the coefficient of performance and it had positive effects on the refrigerating capacity. Bolaji [69] theoretically assessed the performance of a VCRS at an evaporating temp of $-20^{\circ} \mathrm{C}$ and a condensing temperature of $40{ }^{\circ} \mathrm{C}$ working with the refrigerants R432A and R433A. It was reported that the two alternative refrigerants, consistently exhibited better performance than R22 in sub-cooling heat exchanger refrigeration system.

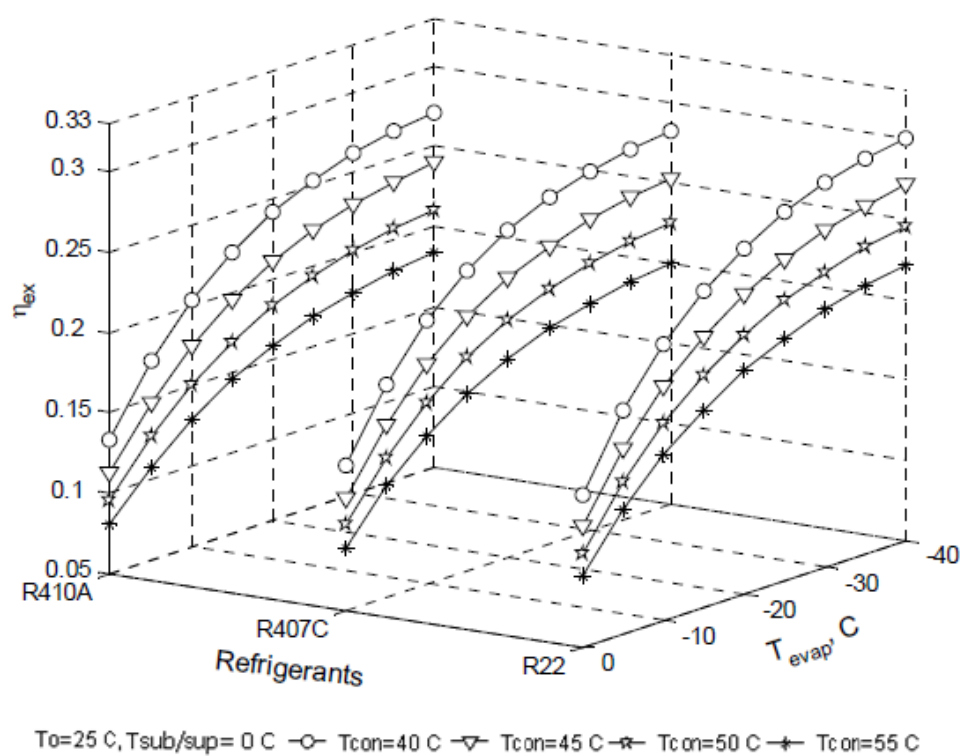

Figure 2. Effect of condenser temperature on exergetic efficiency [8]

\section{Based on Cooling Capacity}

Up to $3.5 \mathrm{~kW}$ capacity Lampugnani and Zgliczynski [70] investigated R290 as an alternative for R22 in a $1.8 \mathrm{~kW}$ air conditioner. Their results revealed that the hermetic compressors, designed for use with R22, while 
operating with propane show a strong benefit in terms of general reliability, due to the lower bearing loads and the lower thermal level. It has a positive influence on the risk associated to the use of flammable refrigerants. Zaghdoudi [71] simulated the performance of a $2.63 \mathrm{~kW}$ residential air conditioner using refrigerants R134A, R290, R600, R404A, R407A, R407B, R407C, 407D, R410A, R410B, and R417A as alternatives to R22. R290 was identified as the best candidate for R22.

$3.5 \mathrm{~kW}$ to $7 \mathrm{~kW}$ capacity Devotta et al. [72] experimentally investigated the performance of propane as alternative to R22 in a $5.13 \mathrm{~kW}$ window air conditioner at an evaporating temperature of $7.4^{\circ} \mathrm{C}$ and a condensing temperature of $35^{\circ} \mathrm{C}$. Their results showed that cooling capacity of HC-290 was lower in the range $6.6-9.7 \%$ but energy consumption with HC-290 was lower in the range 12.4-13.5\%. Discharge pressures of HC-290 were lower in the range 13.7-18.2\%. Al-Joudi \& Al-Amir [73] have studied the performance (both theoretically and experimentally) of a split type air conditioner of 2 TR working with refrigerants R290, R407C and R410A. It was reported that R290 is the better replacement for R22 when the air conditioning system works under high ambient temperature. R407C has the closest performance to R22, followed by R410A.

Above $7 \mathrm{~kW}$ capacity Agrawal et al. [74] simulated the performance of a $28.64 \mathrm{~kW}$ bulk milk cooler using refrigerants R1270 and R32/R152 as alternatives to R22. R1270 was identified as best choice for replacing R22 with zero ODP and negligible GWP. Out of four mixtures, R32/R152 is best with zero ODP and low GWP. Zakrzewski \& Lokietek [75] compared the performance of a $25 \mathrm{~kW}$ heat pump working with R22 and its alternatives (R41, R152A, R218, R227ea, RC318, R600A, R290, and R1270). They suggested that despite their good properties for air conditioning, wider use of R600A, R152A, R290, and R1270 is limited because of their high combustibility.

\section{Based on Changes in Components of the System}

Chinnaraj et al. [76] experimented with R407C and R290 in a $3.5 \mathrm{~kW}$ window air conditioner. It has been reported that the electronic expansion valve shows good overall performances comparing the capillary tube system. The coefficient of performance of R290 is the maximum among the three refrigerants tested. Cheng et al. [77] experimentally investigated the performance of R 32 and R290 as alternatives to R22 in a $2.9 \mathrm{~kW}$ small split household air conditioner with $5 \mathrm{~mm}$ finned tube heat exchanger. Their results showed that COP of R32 and R290 were $26.8 \%$ and $20.4 \%$ higher than R22 and 7.3\% and 2.1\% higher than R410A. The systems with R290 and R32 have huge difference of capacities to that with R22 and R410A. In consideration of charge amount, R290 could be considered as the most superior alternative refrigerant in air conditioners with the small finned tube heat exchanger. Padalkar et al. [78] experimentally studied the performance and flammability of R290 in split air conditioners with nominal cooling capacities up to $5.1 \mathrm{~kW}$. Their results concluded that with PFC (parallel flow condenser), HC-290 gave highest EER of 3.7 which was 37\% higher than that of HCFC-22. The lowest HC-290 charge used in test was $340 \mathrm{~g}$ which is well below LFL (lower flammability limit).

\section{Performance Comparison}

Figure 3 shows the variation of COP of HC 290 with evaporation as well as condenser temperature in comparison with R22 (Boumaza [64]). Figure 4 depicts the COP and volumetric refrigerating capacity (VRC) of R290 and other alternative refrigerants relative to R22 (Saleh and Wendland [57]).

\section{Refrigerant Mixtures}

Domanski and Didion [79] suggested a semi-theoretical model for residential heat pumps working with R32/125 (60/40), R32/125/134A/290 (20/55/20/5), R32/125/134A (10/70/20) and (30/10/60), R290, R32/227ea (35/65), R32/134A (25/75) and (30/70), and R134A (the refrigerant mixture blending being on mass basis). Their results indicated that higher pressure fluids demonstrated a higher volumetric capacity and a lower COP. A strong exception was the high-glide R32/227ea mixture, of which the performance was penalized by use of pure crossflow heat exchangers. Using the llsl-hx may be warranted for some of the candidate fluids. Devotta [80] studied the performance of a propane and butane mixture in a heat pump and reported some improvement in COP at the cost of risk of flammability. In a similar study, Chang et al. [81] assessed the performance of propane/isobutane/butane/propylene/propane, isobutane mix/propane, butane mix in a heat pump and concluded that the capacity and COP of R1270 are slightly greater than that of R22, which is an indication of a possible alternative for air conditioning and heat pumping applications. The COP of hydrocarbon mixtures for the cooling condition is higher than that of R22 for a wide range of the mixture compositions. Jung et al. [82] analysed the 
performance of 14 refrigerant mixtures composed of R32, R125, R134A, R152A, R290 (propane) and R1270 (propylene) and reported that 26\% R32 / 14\% R125 / 60\% R134A (the refrigerant mixture blending being on mass basis), has better performance than R407C. COPs of the binary mixtures composed of R32 and R134A are $7 \%$ higher and their capacities are similar to those of HCFC22. Both COP and capacity of the binary azeotrope of R290 and R134a are 3-5\% higher than those of HCFC22.

Roberts and Chambers [83] experimented with R417A \& Blend 79(R125/R134A/R600A $(85.1 \% / 11.5 \% / 3.4 \%)$ ) in an air conditioner (the refrigerant mixture blending being on mass basis). During their experimentation, the operating temperatures were maintained at $56^{\circ} \mathrm{C}, 48$ to $50^{\circ} \mathrm{C} \& 58 \mathrm{C}$ (condenser temperature) and 5, $10.8 \&-2^{\circ} \mathrm{C}$ (evaporator temperature). It has been reported that $\mathrm{R} 417 \mathrm{~A}$ is suitable for air conditioning with no problems experienced through lack of capacity, but energy savings were experienced. Blend 79 has been demonstrated to be suitable for use as a replacement for R22 with minimal changes to the expansion valves. Arcaklioglu [84] compared the performance of R32/R134A-25/75, R32/R134A-30/70, R32/R125/R134A-30/10/60， R290/R134A-46/54， 32/R125/R290/R134A-20/55/5/20， R32/R125-50/50, $\mathrm{R} 32 / \mathrm{R} 125 / \mathrm{R} 134 \mathrm{~A}-10 / 70 / 20$ and R22 in a compression-based refrigeration system (the refrigerant mixture blending being on mass basis). It was reported that for R22, R32/R125/R134A (32.5/5/62.5) mixture provides $0.8 \%$ better COP.

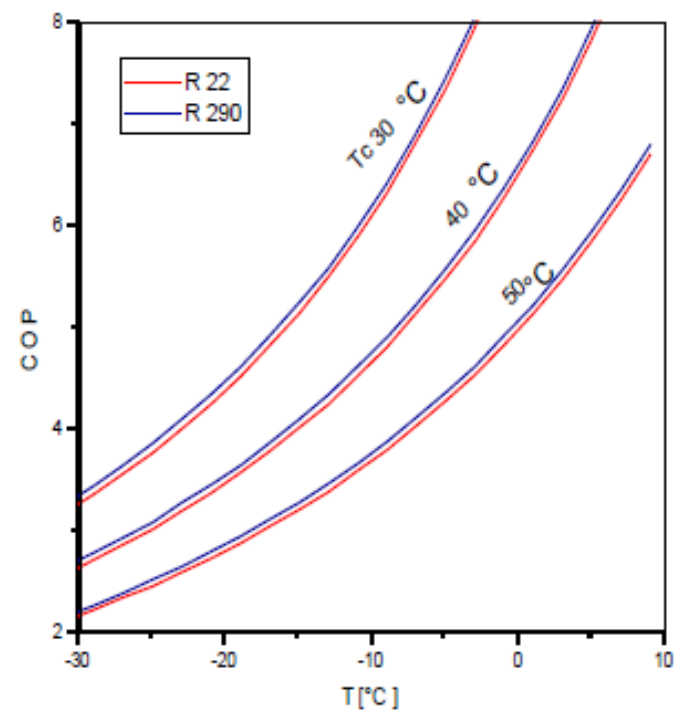

Figure 3. Variation of the Coefficient of performance with respect to Tev and Tcond, for HC 290 and R22 [64]

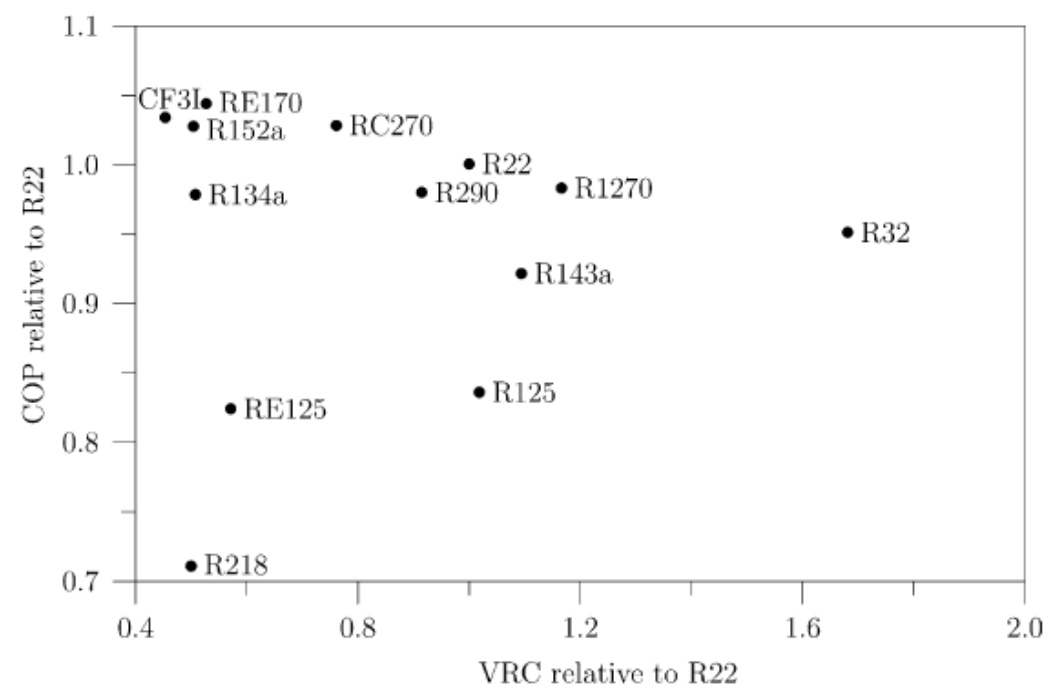

Figure 4. COP and VRC of alternative refrigerants relative to R22 [57] 
Park et al. [85] have conducted an experimental investigation in R22-based air-conditioners and heat pumps working with propylene, propane and seven mixtures composed of propylene, propane, HFC152A, and dimethyl ether as alternatives. It has been reported that COP of these mixtures is up to 5.7\% higher than that of R22. Propane showed an $11.5 \%$ reduction in capacity while most of the fluids had a similar capacity to that of R22. The compressor-discharge temperatures were reduced by $11-17^{\circ} \mathrm{C}$ and the amount of charge was reduced by up to 55\% as compared to HCFC22. Park et al. [86] experimentally studied the thermodynamic performance of $\mathrm{R} 433 \mathrm{~A}$ ( $30 \%$ propylene and $70 \%$ propane) as alternative for R22 in air-conditioners and heat pumps (the refrigerant mixture blending being on mass basis). The results reported in their study are compared in Table 2 . It is found that the COP of $\mathrm{R} 433 \mathrm{~A}$ is $4.9-7.6 \%$ higher and the capacity of $\mathrm{R} 433 \mathrm{~A}$ is $1.0-5.5 \%$ lower. The compressor discharge temp of $\mathrm{R} 433 \mathrm{~A}$ is $22.6-27.9^{\circ} \mathrm{C}$ lower while the amount of charge for $\mathrm{R} 433 \mathrm{~A}$ is $57.0-$ $57.7 \%$ lower.

In another experimental study, Park et al. [87] also compared the performance of R432A in a heat pump bench tester and concluded that the COP of R432A is $8.5-8.7 \%$ higher than that of R22 and the capacity of $\mathrm{R} 432 \mathrm{~A}$ is $1.9-6.4 \%$ higher than that of $\mathrm{R} 22$. The compressor discharge temp of $\mathrm{R} 432 \mathrm{~A}$ is $14.1-17.3^{\circ} \mathrm{C}$ lower than that of R22 whereas the amount of charge for R432A is 50\% lower than that of R22 due to its low density. Cleland et al. [88] conducted experimental studies on an on-farm milk cooling working with Care-50 [a mixture of propane (R-290) and ethane (R-170)] as an alternative to R22. It was reported that Care-50 reduced energy use by $6-8 \%$ and had similar system cooling capacity relative to HCFC-22. The small charge means that hydrocarbons could meet standards for safe use of refrigerants.

Allgood \& Lawson [89] experimented with R438A in existing refrigeration \& air conditioning systems and reported that compared to R22, similar cooling performance \& energy efficiency were achieved. Lower discharge temperature and similar evaporator \& condenser pressure were observed with no change of lubricant during retrofit. BOCK Compressors [90] tested R422D (MO29), R417A (MO59) and R438A (MO99) in their compressors and found that among the three alternative refrigerants, the compression temperature was the lowest for R417A; R438A had the highest refrigerating capacity while R417A had the highest energy efficiency, in comparison to R22. Lopez [91] reported that R434A is the only possible direct solution on the market for the range of temperatures in air conditioning while emphasizing to use this refrigerant with adjustable expansion devices in order to set the correct superheat.

Cabello et al. [92] conducted experimental studies on single-stage vapour compression refrigeration plant working with drop-in fluids R417B and R422A and long-term substitute R404A. Their results showed that use of IHX allows the drop-in fluids to approximate the energy performance of R22, especially in the case of R417B. Ramu et al. [93] investigated a new mixtureR32/R125/R600A (in the ratio of 0.4:0.4:0.2, by mass) as an alternative for R22 in an air conditioner. Their results revealed that VCC of new refrigerant mixture is closer to R22 and COP of the mixture was found to be lower by about 16-20\%. The compressor discharge temperature of the new refrigerant mixture was observed to be $6-11^{\circ} \mathrm{C}$ lower and TEGWI of new refrigerant mixture was found to be higher than that of R22 by about 20\%. Dalkilic et al. [94] theoretically analysed the performance of various alternative refrigerants in a shell and tube condenser at an evaporating temp of $-10{ }^{\circ} \mathrm{C}$ and a condensing temperature of 35 to $55^{\circ} \mathrm{C}$.

Table 2. Test results for HCFC22 and R433A under air-conditioning condition [86]

\begin{tabular}{|c|c|c|c|c|c|c|c|c|c|}
\hline Refrigerants & $\mathbf{C O P}$ & $\begin{array}{c}\text { Diff in } \\
\text { COP }(\boldsymbol{\%})\end{array}$ & $\begin{array}{c}\mathbf{Q}_{\mathbf{e}} \\
(\mathbf{W})\end{array}$ & $\begin{array}{c}\text { Diff in } \\
\mathbf{Q}_{\mathbf{c}}(\boldsymbol{\%})\end{array}$ & $\begin{array}{c}\mathbf{W} \\
(\mathbf{W})\end{array}$ & $\begin{array}{c}\text { Diff in } \\
\mathbf{W}(\boldsymbol{\%})\end{array}$ & $\mathbf{P R}$ & $\mathbf{T}_{\text {dis }}\left({ }^{\mathbf{}} \mathbf{C}\right)$ & $\begin{array}{c}\text { Charge } \\
(\mathbf{g})\end{array}$ \\
\hline HCFC22 & 3.41 & & 3734 & & 1096 & & 2.99 & 84.7 & 1300 \\
\hline R433A & 3.67 & 7.6 & 3527 & -5.5 & 960 & -12.4 & 2.52 & 62.1 & 550 \\
\hline
\end{tabular}

The results showed that the refrigerant mixture of R290/R600, R152a/R125/R32 and R32/R134a were the most proper replacement refrigerant among the alternatives. Figure 5 compares the saturation pressure vs temperature of R422D and R22 (Aprea et al. [39]). Figure 6 shows the variation of COP of R422D with refrigeration duty in comparison to R22 (Aprea et al. [39]). 


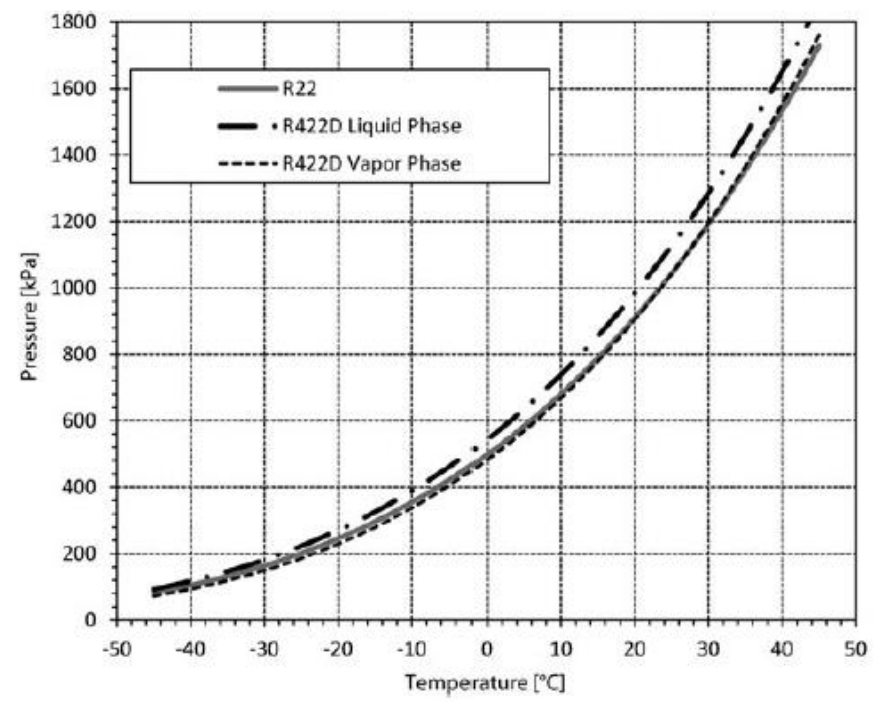

Figure 5. Comparison of saturation pressure vs. temperature of R422D and R22 [39]

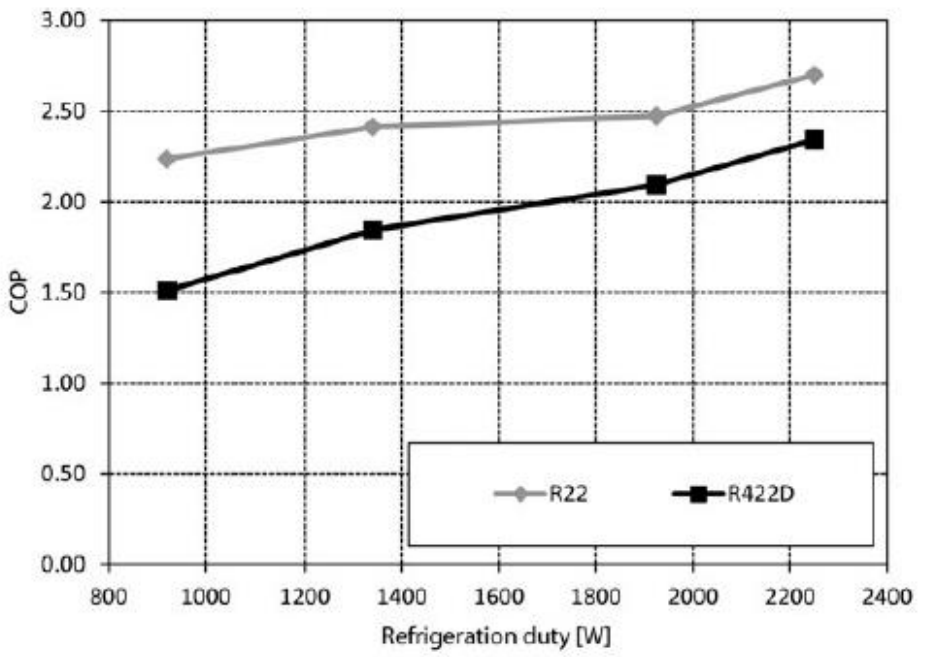

Figure 6. Comparison of COP vs. refrigeration duty for R22 and R422D [39]

\section{Other Refrigerants}

Lorentzen [95] in a study on vapour compression refrigeration system suggested that, in the conventional refrigeration and heat pump domain three refrigerants will be sufficient to satisfy normal requirements: $\mathrm{NH}_{3}, \mathrm{R} 290 \& \mathrm{CO}_{2}$. McMullan [96] reported that due to the failure to find single fluid replacement fluids in most applications, the potential role for fluid mixtures and natural refrigerants like $\mathrm{NH}_{3}, \mathrm{HCs} \& \mathrm{CO}_{2}$, has had to be re-examined. Tao et al. [97] tested the performance of $\mathrm{CO}_{2}$ in a transcritical $\mathrm{CO}_{2}$ system at evaporating temperature of 10 to $14^{\circ} \mathrm{C}$ and their results showed that CO2 has zero ODP, negligible GWP and very low cost. So, $\mathrm{CO}_{2}$ is an excellent alternative to the traditional refrigerants. The average relative exergy losses in gas cooler and expansion valve are the dominant exergy losses in the transcritical $\mathrm{CO}_{2}$ residential airconditioning system. Benhadid-Dib \&Benzaoui [98] reported that there is merit of redeploying natural refrigerants as an alternative solution to replace halogenated refrigerants. Sarbu\&Valea [99] suggested that a possible solution is the use of inorganic refrigerants $\left(\mathrm{NH}_{3}, \mathrm{CO}_{2}\right)$ and hydrocarbon refrigerants (propane, isobutene, ethylene, propylene) in air conditioning. Because the hydrocarbon refrigerant presents a high risk of flammability and explosion, these substances will not be often used as refrigerants comparative with $\mathrm{CO}_{2}$ or $\mathrm{NH}_{3}$.

Figure 7 depicts the variation of the volumetric refrigerating capacity of R717 and R22 with respect to evaporator temperature and condenser temperature. Figure 8 shows the variation of $\mathrm{COP}$ of $\mathrm{NH}_{3}(\mathrm{R} 717)$ with evaporator temperature as well as condenser temperature in comparison with R22 (Boumaza [64]). 


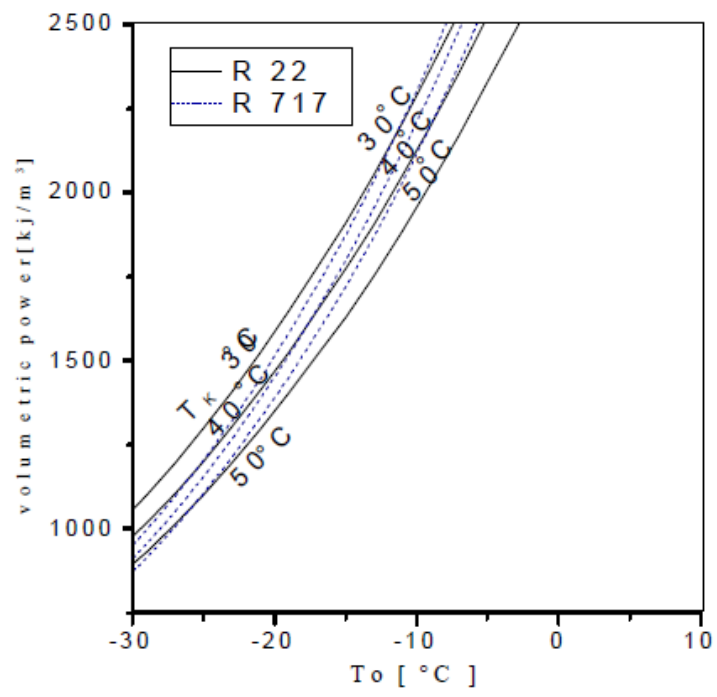

Figure 7. Variation of the volumetric refrigerating capacity of R717 andR22 with respect to $T_{0}$ (evaporator temperature) and $\mathrm{T}_{\mathrm{c}}$ (condenser temperature) [64]

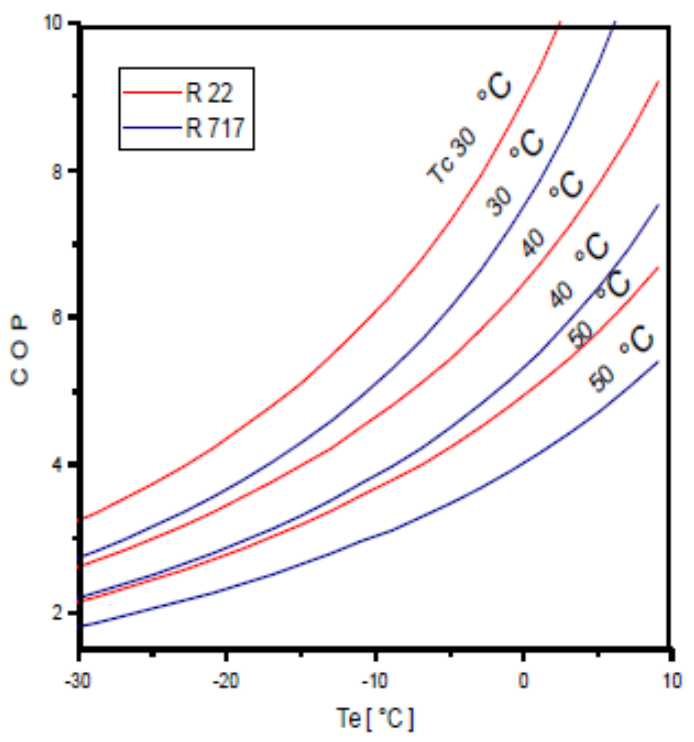

Figure 8. Variation of the Coefficient of performance with respect to $T_{e}$ (evaporator temperature) and $T_{c}$ (condenser temperature), for R717 and R22 [64]

\section{RESULTS AND DISCUSSION}

HFCs that replaced CFCs in the last decade have high GWP and need to be eventually phased out. Environment friendly natural refrigerants such as ammonia, carbon dioxide, hydrocarbons have specific practical deficiencies that limit their universal use. Thus, there are no refrigerants in the horizon that completely meet the safety, stability, energy efficiency and environmental friendliness. The refrigerants HC290 and HC1270 seem to be the most near to R22 in terms of their thermodynamic performance. Although easily available and having low cost, they have the drawback of being flammable as both belong to ASHRAE safety group A3. The next available choice is the HFCs. The drawback of HFCs is that they have high GWP. R407C has GWP of 1700 whereas that of $\mathrm{R} 410 \mathrm{~A}$ is 2000 . The third option is to use natural refrigerants $\mathrm{NH}_{3}(\mathrm{R} 717)$ and $\mathrm{CO}_{2}(\mathrm{R} 744)$. The drawback of using $\mathrm{CO}_{2}$ is that it necessitates high pressures in the system and $\mathrm{NH}_{3}$ is toxic and flammable in nature. This narrows down the choice of alternative refrigerant of R22 to a mixture of HFCs and HCs which are mixed in such a ratio that GWP is kept to a minimum, flammability is within accepted limits and the refrigerant mixture is miscible in the conventional cheap lubricant i.e. mineral oil. 


\section{CONCLUDING REMARKS}

Alternatives for R22 in air-conditioning can be grouped into four types: HFC, HC, other natural substances and refrigerant mixtures. The most popular HFC, R410A is having lower critical temperature, which restricts its usage in compression-based systems working at higher condensing temperatures. Whereas for $\mathrm{R} 407 \mathrm{C}$, a change to synthetic lubricant is required and $\mathrm{HC}-290$ is flammable. The conventional $\mathrm{CO}_{2}$ systems require high power consumption and lose capacity at high temperature. $\mathrm{NH}_{3}$ has high toxicity and high initial costs. In view of the above it is suggested that until the safety issue of use of hydrocarbon refrigerants in quantities exceeding 500gm is resolved, we should go for those mixtures of HFCs and HCs for which TEWI index is the lowest.

\section{NOMENCLATURE}

HCFC Hydrochloroflurocarbon

ODP Ozone depleting potential

HC Hydrocarbon

COP Coefficient of performance

EDR Exergy destruction ratio

VCRS Vapour compression refrigeration system

EER Energy efficiency ratio

\section{REFERENCES}

[1] Poggi, F., Macchi-Tejeda, H., Leducq, D., \& Bontemps, A. (2008). Refrigerant charge in refrigerating systems and strategies of charge reduction. International Journal of Refrigeration, 31(3), 353-370.

[2] Palm, B. (2008). Hydrocarbons as refrigerants in small heat pump and refrigeration systems-a review. International journal of refrigeration, 31(4), 552-563.

[3] Calm, J. M. (2008). The next generation of refrigerants-Historical review, considerations, and outlook. international Journal of Refrigeration, 31(7), 1123-1133.

[4] Mohanraj, M., Muraleedharan, C., \& Jayaraj, S. (2011). A review on recent developments in new refrigerant mixtures for vapour compression-based refrigeration, air-conditioning and heat pump units. International journal of energy research, 35(8), 647-669.

[5] Sarbu, I. (2014). A review on substitution strategy of non-ecological refrigerants from vapour compressionbased refrigeration, air-conditioning and heat pump systems. International Journal of Refrigeration, 46, 123-141.

[6] Arora, A., Arora, B. B., Pathak, B. D., \& Sachdev, H. L. (2007). Exergy analysis of a vapour compression refrigeration system with R-22, R-407C and R-410A. International journal of Exergy, 4(4), 441-454.

[7] Du Pont (accessed Jan 14, 2015). http://www.isceon.com/uk

[8] Menlik, T., Demircioğlu, A., \& Özkaya, M. G. (2013). Energy and exergy analysis of R22 and its alternatives in a vapour compression refrigeration system. International Journal of Exergy, 12(1), 11-30.

[9] Klein, S. A., Reindl, D. T., \& Brownell, K. (2000). Refrigeration system performance using liquid-suction heat exchangers. International Journal of Refrigeration, 23(8), 588-596.

[10] Grace, I. N. \& Tassou, S. A. (2000). In Simulation of the performance of alternative refrigerants in liquid chillers, International Refrigeration and Air Conditioning Conference Paper 513.

[11] Boumaza, M. M. (2007). A numerical Investigation and Comparison of Chlorines Compounds Refrigerants and their Potential Substitutes Operating at High Ambient Temperature Case for the Replacement of R22. Final Research Report.

[12] Rani, T. U., \& Balachander, P. (2008). Numerical simulation of fin and tube condenser in a R22 system charged with R407C.

[13] Jia, S. (2009). Evaluation of HCFC alternative refrigerants. Heatcraft Worldwide Refrigeration.

[14] Aprea, C., Maiorino, A., \& Mastrullo, R. (2011). Change in energy performance as a result of a R422D retrofit: An experimental analysis for a vapor compression refrigeration plant for a walk-in cooler. Applied energy, 88(12), 4742-4748.

[15] Han, X. H., Qiu, Y., Li, P., Xu, Y. J., Wang, Q., \& Chen, G. M. (2012). Cycle performance studies on HFC161 in a small-scale refrigeration system as an alternative refrigerant to HFC-410A. Energy and Buildings, 44, 33-38.

[16] Padmanabhan, V. M. V., \& Palanisamy, S. K. (2013). Exergy efficiency and irreversibility comparison of R22, R134a, R290 and R407C to replace R22 in an air conditioning system. Journal of Mechanical Science and Technology, 27(3), 917-926.

[17] Bolaji, B. O., Abiala, I. O., Ismaila, S. O., \& Borokinni, F. O. (2014). A theoretical comparison of two ecofriendly refrigerants as alternatives to $\mathrm{r} 22$ using a simple vapour compression refrigeration system. Transactions of FAMENA, 38(3), 59-70. 
[18] La Rocca, A., La Rocca, V., Messineo, A., \& Panno, D. (2014). Use of HFC fluids as suitable replacements in low-temperature refrigeration plants. Journal of Engineering and Applied Sciences, 9(1, Gennaio 2014), 7479.

[19] Hewitt, N. J., \& McMullan, J. T. (1997). The replacement of CFCs in refrigeration equipment by environmentally benign alternatives. Applied thermal engineering, 17(8-10), 955-972.

[20] Johansson, A., \& Lundqvist, P. (1998). Optimal distribution of Condenser area for Retrofits. International Refrigeration and Air Conditioning Conference.

[21] Devotta, S., Waghmare, A. V., Sawant, N. N., \& Domkundwar, B. M. (2001). Alternatives to HCFC-22 for air conditioners. Applied Thermal Engineering, 21(6), 703-715.

[22] Johansson, A., \& Lundqvist, P. (2003). Replacement of R22 in existing installations: experiences from the Swedish phase out. Royal Institute of Technology, Department of Energy Technology, Stockholm, Sweden. [23] Calm, J. M., \& Domanski, P. A. (2004). R-22 replacement status. ASHRAE journal, 46(8), 29.

[24] Horuz, I. (2004). Ozone-depleting substances, phase-out program and alternatives. International communications in heat and mass transfer, 31(4), 607-618.

[25 Chen, J., \& Yu, J. (2008). Performance of a new refrigeration cycle using refrigerant mixture R32/R134a for residential air-conditioner applications. Energy and Buildings, 40(11), 2022-2027.

[26] Allgood, C. (2008). Refrigeration Regulations, Outlook, Transitions \& Alternatives. ASHRAE Meeting 11 November.

[27] Emerson Network Power (2009). Comparing R407C and R410A as Alternatives for R22. http:/www. EmersonNetworkPower.com.

[28] Honeywell (accessed Jan 14, 2015). http//www.genetron.com

[29] Department for Environment, Food and Rural Affairs, UK, (2012). Guidance: F Gas and Ozone Regulations.

[30] Bitzer (accessed Jan 14, 2015). http://www.bitzer.de

[31] Bolaji, B. O. (2012). Performance of A R22 split-air-conditioner when retrofitted with ozone friendly refrigerants (R410A and R417A). Journal of Energy in Southern Africa, 23(3), 16-22.

[32] Vjacheslav, N., Rozhentsev, A., \& Wang, C. C. (2001). Rationally based model for evaluating the optimal refrigerant mass charge in refrigerating machines. Energy Conversion and Management, 42(18), 2083-2095.

[33] Aprea, C., \& Renno, C. (2004). Experimental comparison of R22 with R417A performance in a vapour compression refrigeration plant subjected to a cold store. Energy conversion and management, 45(11-12), 18071819 .

[34] Spatz, M. W., \& Motta, S. F. Y. (2004). An evaluation of options for replacing HCFC-22 in medium temperature refrigeration systems. International Journal of Refrigeration, 27(5), 475-483.

[35] Chen, W. (2008). A comparative study on the performance and environmental characteristics of R410A and R22 residential air conditioners. Applied thermal engineering, 28(1), 1-7.

[36] Mohanraj, M., Jayaraj, S., \& Muraleedharan, C. (2009). Environment friendly alternatives to halogenated refrigerants - A review. International Journal of Greenhouse Gas Control, 3(1), 108-119.

[37] Wang, F. J., Tsai, K. I., Wang, Y. J., \& Lee, H. C. (2011). Experimental investigation of a process cooling system retrofitted with HFC-404A refrigerant for precise manufacturing application. Journal of Mechanical Science and Technology, 25(2), 495-501.

[38] Wu, Y., Liang, X., Tu, X., \& Zhuang, R. (2012). Study of R161 refrigerant for residential air-conditioning applications. International Refrigeration and Air Conditioning Conference Paper 1189.

[39] Aprea, C., Maiorino, A., \& Mastrullo, R. (2012). Exergy analysis of a cooling system: experimental investigation on the consequences of the retrofit of R22 with R422D. International Journal of Low-Carbon Technologies, 9(1), 71-79.

[40] Bensafi, A., Mondot, M., \& Durier, F.F. (1997). Experimental evaluation of some proposed R22 alternatives in chillers and unitary $\mathrm{A} / \mathrm{C}$ equipment. Clima. Centre Technique des Industries Aérauliques et Thermiques (CETIAT), France.

[41] Aprea, C., \& Greco, A. (2002). An exergetic analysis of R22 substitution. Applied Thermal Engineering, 22(13), 1455-1469.

[42] Devotta, S., Padalkar, A. S., \& Sane, N. K. (2005). Performance assessment of HCFC-22 window air conditioner retrofitted with R-407C. Applied Thermal Engineering, 25(17-18), 2937-2949.

[43] Bolaji, B. O. (2011). Performance investigation of ozone-friendly R404A and R507 refrigerants as alternatives to R22 in a window air-conditioner. Energy and Buildings, 43(11), 3139-3143.

[44] Samuel, K. J., Govindarajulu, K., \& Edison, G. (2014). An Experimental Investigation and Performance Evaluation of 1.5 TR Window Air-Conditioner by Using R22 R407C and R410A by Varying the Capillary Pitch. World Applied Sciences Journal, 29(11), 1468-1472.

[45] Payne, W. V., \& Domanski, P. A. (2002). A comparison of an R22 and an R410a air conditioner operating at high ambient temperatures. National Institute of Standards and Technology Building Environment Division: Thermal Machinery Group Gaithersburg, Maryland, USA. 
[46] Hwang, Y., Jin, D. H., \& Radermacher, R. (2007). Comparison of R-290 and two HFC blends for walk-in refrigeration systems. International Journal of Refrigeration, 30(4), 633-641.

[47] Kulcar, B., Goricanec, D., \& Krope, J. (2010). Economy of replacing a refrigerant in a cooling system for preparing chilled water. international journal of refrigeration, 33(5), 989-994.

[48] La Rocca, V., \& Panno, G. (2011). Experimental performance evaluation of a vapour compression refrigerating plant when replacing R22 with alternative refrigerants. Applied energy, 88(8), 2809-2815.

[49] La Rocca, V., Messineo, A., \& Panno, D. (2011, June). An experimental study of a refrigerating plant when replacing R22 with HFCs refrigerants. In XIV European Conference "The Latest Technologies in Air Conditioning and Refrigeration Industry”. IT.

[50] Jain, V., Kachhwaha, S. S., \& Mishra, R. S. (2011). Comparative performance study of vapour compression refrigeration system with R22/R134a/R410A/R407C/M20. International journal of energy and environment, 2(2), 297-310.

[51] Qureshi, B. A., \& Zubair, S. M. (2011). Performance degradation of a vapor compression refrigeration system under fouled conditions. International Journal of Refrigeration, 34(4), 1016-1027.

[52] Lee, D. Y., Ahn, Y., Kim, Y., Chang, Y. S., \& Nam, L. (2002). Experimental investigation on the drop-in performance of $\mathrm{R} 407 \mathrm{C}$ as a substitute for R22 in a screw chiller with shell-and-tube heat exchangers. International journal of refrigeration, 25(5), 575-585.

[53] Aprea, C., Mastrullo, R., Renno, C., \& Vanoli, G. P. (2004). An evaluation of R22 substitutes performances regulating continuously the compressor refrigeration capacity. Applied Thermal Engineering, 24(1), 127-139.

[54] Llopis, R., Cabello, R., Sánchez, D., Torrella, E., Patiño, J., \& Sánchez, J. G. (2011). Experimental evaluation of HCFC-22 replacement by the drop-in fluids HFC-422A and HFC-417B for low temperature refrigeration applications. Applied Thermal Engineering, 31(6-7), 1323-1331.

[55] Subiantoro, A., \& Ooi, K. T. (2013). Economic analysis of the application of expanders in medium scale airconditioners with conventional refrigerants, R1234yf and CO2. international journal of refrigeration, 36(5), $1472-1482$.

[56] Jürgensen, H. (2016). Propane as R22-Replacement in Commercial Appliances. Danfoss Compressors $\mathrm{GmbH}$.

[57] Saleh, B., \& Wendland, M. (2006). Screening of pure fluids as alternative refrigerants. International journal of refrigeration, 29(2), 260-269.

[58] Granryd, E. (2001). Hydrocarbons as refrigerants - an overview. International journal of refrigeration, 24(1), 15-24.

[59] Copetti, J. B., Macagnan, M. H., Geyer, M., \& Oliveski, R. C. (2005). The use of hydrocarbons propane and isobutane in refrigeration systems. In 18 th International Congress of mechanical Engineering-COBEM.

[60] Park, K. J., \& Jung, D. (2008). Performance of R290 and R1270 for R22 applications with evaporator and condenser temperature variation. Journal of Mechanical Science and Technology, 22(3), 532-537.

[61] Bayrakçi, H. C., \& Özgür, A. E. (2009). Energy and exergy analysis of vapor compression refrigeration system using pure hydrocarbon refrigerants. International Journal of Energy Research, 33(12), 1070-1075.

[62] Park, K. J., Lee, Y., \& Jung, D. (2010). Performance of R170/R1270 mixture under air-conditioning and heat pumping conditions. Journal of mechanical science and technology, 24(4), 879-885.

[63] Dalkilic, A. S., \& Wongwises, S. (2010). A performance comparison of vapour-compression refrigeration system using various alternative refrigerants. International Communications in Heat and Mass Transfer, 37(9), $1340-1349$.

[64] Boumaza, M. (2010). Performances assessment of natural refrigerants as substitutes to CFC and HCFC in hot climate. Int. J. of Thermal \& Environmental Engineering, 1(2), 125-130.

[65] Wan, T., Dou, Y., Wang, L., Yang, L., Zhou, X., Wan, D., \& Hu, J. (2011). Environmental benefits for phaseout HCFC-22 in the residential air-conditioner sector in China. Advances in Climate Change Research, 2(2), 8692.

[66] Farraj, A., Mallouh, M. A., Kalendar, A. R., \& Al-Rzaq, A. (2012). Experimental Study of Solar Powered Air Conditioning Unit Using Drop-In Hydro Carbon Mixture to Replace R-22. JJMIE, 6(1).

[67] Prapainop, R. \& Suen, K.O. (2012). Simulation of potential refrigerants for retrofit replacement. ARPN Journal of Engineering \& Applied Science, 7(9), 1146-1151.

[68] Bolaji, B. O., \& Huan, Z. (2012). Comparative analysis of the performance of hydrocarbon refrigerants with R22 in a sub-cooling heat exchanger refrigeration system. Proceedings of the Institution of Mechanical Engineers, Part A: Journal of Power and Energy, 226(7), 882-891.

[69] Bolaji, B. (2014). Influence of sub-cooling on the energy performance of two ecofriendly R22 alternative refrigerants. Journal of Science and Technology (Ghana), 34(2), 73-83.

[70] Lampugnani, G., \& Zgliczynski, M. (1996). R290 as a Substitute of R502 and R22 in Commercial Refrigeration and Air Conditioning, International Compressor Engineering Conference Paper 1087. 
[71] Zaghdoudi, M. C., Maalej, S., Saad, Y., \& Bouchaala, M. (2010). A comparative study on the performance and environmental characteristics of alternatives to R22 in residential air conditioners for Tunisian market. Journal of Environmental Science and Engineering, 4(12).

[72] Devotta, S., Padalkar, A. S., \& Sane, N. K. (2005). Performance assessment of HC-290 as a drop-in substitute to HCFC-22 in a window air conditioner. International Journal of Refrigeration, 28(4), 594-604.

[73] Lect, K., \& Al-Amir, Q. (2014). Performance evaluation of small scale air-conditioning system using R22 and alternative refrigerants. Journal of Engineering, 20(1).

[74] Agrawal, A. B., Dave, R. K., \& Shrivastava, V. (2009). Replacing harmful refrigerant R22 in a bulk milk cooler. Indian Journal of Science and Technology, 2(9), 51-58.

[75] Zakrzewski, B., \& Łokietek, T. (2010). Assessing the applicability of new refrigerants in marine cooling systems. Polish Maritime Research, 17(2), 55-59.

[76] Chinnaraj, C., Govindarajan, P., \& Vijayan, R. (2011). Influence of electronic expansion valve on the performance of small window air conditioner retrofitted with R407C and R290. Thermal Science, 15(suppl. 2), 327-339.

[77] Cheng, S., Wang, S., \& Liu, Z. (2014). Cycle performance of alternative refrigerants for domestic airconditioning system based on a small finned tube heat exchanger. Applied thermal engineering, 64(1-2), 83-92.

[78] Padalkar, A. S., Mali, K. V., \& Devotta, S. (2014). Simulated and experimental performance of split packaged air conditioner using refrigerant HC-290 as a substitute for HCFC-22. Applied Thermal Engineering, 62(1), 277-284.

[79] Domanski, P. A., \& Didion, D. A. (1993). Theoretical evaluation of R22 and R502 alternatives (No. DOE/CE/23810-7). Air-Conditioning and Refrigeration Technology Inst., Inc., Arlington, VA (United States); National Inst. of Standards and Technology (NEL), Gaithersburg, MD (United States). Building Environment Div.

[80] Devotta, S. (1995). Alternative heat pump working fluids to CFCs. Heat Recovery Systems and CHP, 15(3), 273-279.

[81] Chang, Y. S., Kim, M. S., \& Ro, S. T. (2000). Performance and heat transfer characteristics of hydrocarbon refrigerants in a heat pump system. International journal of refrigeration, 23(3), 232-242.

[82] Jung, D., Song, Y., \& Park, B. (2000). Performance des mélanges de frigorigènes utilisés pour remplacer le HCFC22. International Journal of Refrigeration, 23(6), 466-474.

[83] Roberts, N. A., \& Chambers, O. R. (2004). Energy saving refrigerant blends comprising R125, R134a, R600 or R600a. International Refrigeration and Air Conditioning Conference Paper 632.

[84] Arcaklığlu, E., Çavuşoğlu, A., \& Erişen, A. (2006). Thermodynamic analysis of refrigerant mixtures for possible replacements for CFCs by an algorithm compiling property data. Applied Thermal Engineering, 26(4), 430-439.

[85] Park, K. J., Seo, T., \& Jung, D. (2007). Performance of alternative refrigerants for residential airconditioning applications. Applied energy, 84(10), 985-991.

[86] Park, K. J., Shim, Y. B., \& Jung, D. (2008). Performance of R433A for replacing HCFC22 used in residential air-conditioners and heat pumps. Applied Energy, 85(9), 896-900.

[87] Park, K. J., Shim, Y. B., \& Jung, D. (2009). Experimental performance of R432A to replace R22 in residential air-conditioners and heat pumps. Applied Thermal Engineering, 29(2-3), 597-600.

[88] Cleland, D. J., Keedwell, R. W., \& Adams, S. R. (2009). Use of hydrocarbons as drop-in replacements for HCFC-22 in on-farm milk cooling equipment. international journal of refrigeration, 32(6), 1403-1411.

[89] Allgood, C. C., \& Lawson, C. C. (2010). Performance of R-438A in R-22 refrigeration and air conditioning systems. International Refrigeration and Air Conditioning Conference at Purdue, July 12-15.

[90] Bock Compressors, (accessed Jan 20, 2015). www.bock.de

[91] Lopez, D.L.G. (2010). The replacement of R-22. Gas Technical Department of Gas Servei S.A.

[92] Cabello, R., Torrella, E., Llopis, R., Sánchez, D., \& Larumbe, J. A. (2013). Energy influence of the IHX with R22 drop-in and long-term substitutes in refrigeration plants. Applied Thermal Engineering, 50(1), $260-267$. [93] Ramu, N. S., Kumar, P. S., \& Mohanraj, M. (2014). Energy performance assessment of R32/R125/R600a mixtures as possible alternatives to R22 in compression refrigeration systems. International Journal of Mechanical and Mechatronics Engineering IJMME-IJENS, 14(02), 12-22.

[94] Dalkilic, A. S., Mahian, O., \& Wongwises, S. (2014). Selection of the most suitable refrigerant for a shell and tube condenser. Heat and Mass Transfer, 50(2), 183-197.

[95] Lorentzen, G. (1995). The use of natural refrigerants: a complete solution to the CFC/HCFC predicament. International journal of refrigeration, 18(3), 190-197.

[96] McMullan, J. T. (2002). Refrigeration and the environment-issues and strategies for the future. International Journal of Refrigeration, 25(1), 89-99.

[97] Tao, Y. B., He, Y. L., \& Tao, W. Q. (2010). Exergetic analysis of transcritical CO2 residential airconditioning system based on experimental data. Applied Energy, 87(10), 3065-3072. 
[98] Benhadid-Dib, S., \& Benzaoui, A. (2012). Refrigerants and their environmental impact Substitution of hydro chlorofluorocarbon HCFC and HFC hydro fluorocarbon. Search for an adequate refrigerant. Energy Procedia, 18, 807-816.

[99] Sarbu, I., \& Valea, E. S. Ecological refrigerants used in refrigeration, air-conditioning and heat pump systems. Proceedings of the 2014International Conference on Power Systems, Energy, Environment. 